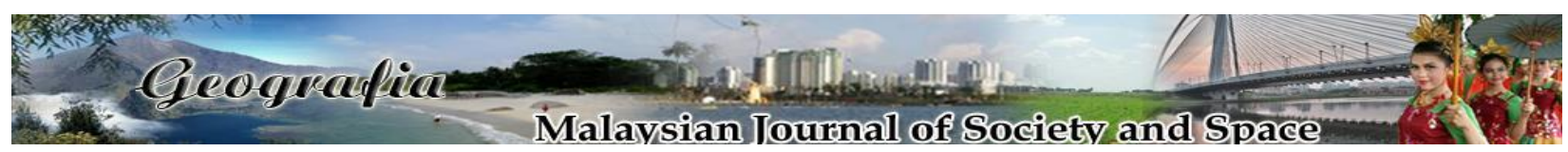

\title{
Rekonstruksi vokal bahasa Minangkabau: Pengintegrasian merentasi geopolitik
}

\author{
Ernawita Atan ${ }^{1}$, Rahim Aman², Shahidi A.H. ${ }^{2}$ \\ ${ }^{1}$ Fakulti Bahasa Moden, Universiti Putra Malaysia \\ ${ }^{2}$ Pusat Kajian Bahasa, Kesusasteraan \& Kebudayaan Melayu, Fakulti Sains Sosial dan Kemanusiaan, \\ Universiti Kebangsaan Malaysia \\ Correspondence: Rahim Aman (email: tuntas@ukm.edu.my)
}

Received: 05 March 2021; Accepted: 07 May 2021; Published: 29 May 2021

\begin{abstract}
Abstrak
Kajian ini memerihalkan tentang pengintegrasian varian Minangkabau antara dua kawasan geopolitik yang serumpun iaitu Semenanjung Malaysia dan Pulau Sumatera, Indonesia. Terdapat banyak kajian yang telah dilakukan berkisar tentang varian Minangkabau. Kajian oleh Chaidir Anwar (1964), Sjam Bachijar (1965) dan Tamsin Medan (1967) bertujuan membandingkan varian Minangkabau untuk mendapatkan bentuk purba fonem vokal dan konsonan juga diftong. Berdasarkan kaedah lapangan, pendekatan semak dan cakap melalui teknik khas telah dilakukan. Objektif kajian ini adalah untuk merekonstruksi vokal Varian Minangkabau Purba yang wujud di Sumatera Indonesia dan Malaysia. Rekonstruksi Varian Minangkabau Purba ini dijalankan dengan menggunakan kaedah perbandingan kualitatif. Rekonstruksi varian ini menggunakan kaedah rekonstruksi dalaman. Kriteria rekonstruksi yang digunakan ialah menentukan kata kognat, mencari perangkat kesepadanan, menentukan rekurensi fonem dan memperoleh fonem purba. Enam belas varian Minangkabau Sumatera, Indonesia dan Semenanjung Malaysia telah diselidiki, iaitu Bangkinang, Paya Kumbuh, varian Tanah Datar, varian Rao, varian Pancung Soal, varian Pangkalan Koto Baru, varian Agam Barat, varian Agam Timur, varian Muara Sg. Labuh, varian Pariaman di Pulau Sumatera. Di Semenanjung Malaysia, kajian dibuat di Negeri Sembilan di Kg. Gagu Jelebu dan Kg. Talang Kuala Pilah, Selangor di Kg. Padang Hulu Langat dan Kg. Ulu Rening Batang Kali, Kg. Sesapan Batu Minangkabau, Beranang dan Pahang di Kg. Janda Baik Bentong. Hasil kajian membuktikan bahawa Varian Minangkabau Purba yang direkonstruksi ini memiliki enam fonem vokal iaitu /i, u, o, e, $\leftrightarrow$ dan a/ yang terdiri daripada satu vokal depan, dua vokal tengah dan dua vokal belakang. Kehadiran fonem-fonem purba iaitu fonem vokal terjadi secara teratur dan mudah dijangka. Keberadaan beberapa ciri sporadik pada fonem vokal memberi gambaran bahawa terjadinya inovasi kerana disebabkan oleh faktor migrasi setempat. Proses ini terjadi hingga menerbitkan ciri inovasi.
\end{abstract}

Kata kunci: Inovasi, perbandingan kualitatif, rekonstruksi, varian, varian Minangkabau, vokal 


\title{
Reconstruction of Minangkabau vowels: Integration across geopolitics
}

\begin{abstract}
This study describes the integration of the Minangkabau variant between two similar geopolitical areas, namely Peninsular Malaysia and Sumatra Island, Indonesia. There are many studies that have been done around the Minangkabau variant. A study by Chaidir Anwar (1964), Sjam Bachijar (1965) and Tamsin Medan (1967) was conducted to compare the Minangkabau variants to obtain the ancient forms of vocal phonemes and consonants as well as diphthongs. Based on field method, the approach of checking and speaking through special techniques has been done. The objective of this study is to reconstruct the vocals of the Ancient Minangkabau Variant that exist in Sumatra Indonesia and Malaysia. This Ancient Minangkabau Variants reconstruction was carried out using a qualitative comparison method. Reconstruction of this variant uses internal reconstruction methods. The reconstruction criteria used were to determine the cognate word, find the matching device, determine the phoneme reconstruction and obtain the ancient phoneme. Sixteen variants of Minangkabau Sumatra, Indonesia and Peninsular Malaysia have been investigated, namely Bangkinang, Paya Kumbuh, Tanah Datar variant, Rao variant, Pancung Soal variant, Pangkalan variant Koto Baru, variant Agam Barat, variant Agam Timur, variant Muara Sg. Labuh, a variant of Pariaman on the island of Sumatra. In Peninsular Malaysia, a study was conducted in Negeri Sembilan in Kg. Gagu Jelebu and Kg. Talang Kuala Pilah, Selangor in Kg. Padang Hulu Langat and Kg. Ulu Rening Batang Kali, Kg. Sesapan Batu Minangkabau, Beranang and Pahang in Kg. Janda Baik Bentong. The results of the study prove that this reconstructed Ancient Minangkabau Variant has six vowel phonemes namely / i, u, o, e, $\leftrightarrow$ and a / which consist of one front vowel, two middle vowels and two back vowels. The presence of ancient phonemes i.e. vowel phonemes occur regularly and is easy to anticipate. The presence of some sporadic features in the consonant phoneme gives the impression that innovation occurs due to local migration factors. This process occurs to publish the characteristics of innovation.
\end{abstract}

Keywords: Innovation, qualitative comparison, reconstruction, variant, Minangkabau variants, vowel

\section{Pengenalan}

Kajian tentang bahasa Minangkabau ini telah dilakukan sejak abad ke-19 lagi. Oleh itu, penerangan dan huraian di bawah ini cuba menyingkap kajian terdahulu bahasa Minangkabau yang telah dilakukan sama ada oleh ahli antropologi, ahli sastera mahupun ahli linguistik. Moussay (1981) telah membuat pembahagian perkembangan kajian bahasa Minangkabau ini kepada tiga tahap. Tahap pertama merupakan penelitian awal yakni dari tahun 1870 hingga 1900. Tahap kedua adalah dari tahun 1920 hingga 1935 yang dikenali sebagai zaman keemasan bagi kajian bahasa Minangkabau manakala, dari tahun 1955 hingga 1980 adalah tahap penerbitan karya-karya bahasa Minangkabau.

Menurut Moussay (1981), pada awalnya kajian dilakukan oleh pengkaji Belanda yang berminat mengkaji bahasa Minangkabau dengan tujuan mencipta sistem transkripsi. Tulisan 
Jawi digunakan pada ketika itu tidak mampu memerihalkan segala ciri bahasa itu. Oleh itu, transkripsi tulisan roman diperlukan untuk menghasilkan sebuah transkripsi bahasa yang tepat untuk membuat perbezaan karya-karya Minang dan Melayu dalam bidang kesusasteraan. Kajian pertama dijalankan oleh J. Pijnappel dan Si Daoed Radja Medan (1872) yang telah menerbitkan sebuah kumpulan cerita pendek dengan tulisan rumi yang bertajuk Minangkabausch-Maleisch Zamen-spraken. Pengkaji-pengkaji lain telah menggunakan bahasa Minangkabau untuk menyampaikan cerita yang berunsurkan tradisional sebagai bahan bacaan yang boleh dibaca oleh lapisan masyarakat.

Varian Minangkabau ini dikaji dari sudut linguistik ketika abad ke-20 dan kajian rekonstruksi sehingga kini, khasnya melalui pendekatan linguistik sejarawi belum pernah dilakukan. Justeru, dalam penulisan ini aspek rekonstruksi ke atas varian Minangkabau akan disoroti dan pendekatan linguistik bandingan sejarawi akan dimanfaatkan. Keutuhan ilmu linguistik bandingan sebenarnya berpaksi kepada usaha-usaha merekonstruksi bentuk purba bahasa manusia. Usaha ini lahir daripada cetusan buah fikiran semua ahli linguistik bandingan untuk membina semula bahasa purba tersebut yang pernah dituturkan oleh penutur-penutur bahasa tersebut pada satu ketika dahulu sebelum bahasa itu terpisah-pisah menjadi serangkaian ragam atau varian-varian tertentu pada ketika ini. Oleh itu, bagi memenuhi tuntutan tugas hakiki ahli linguistik bandingan, maka kajian ini akan membincangkan perkara yang berhubung dengan hal-hal rekonstruksi fonem vokal dan diftong varian Melanau yang akhirnya akan memperoleh pula fonem vokal bahasa Minangkabau Purba (BMP).

\section{Sorotan literatur}

Walaupun terdapat beberapa kajian tentang VM ini, namun didapati belum ada kajian yang dilakukan secara terperinci dalam usaha untuk melakukan rekonstruksi BMP. Himpunan penyelidikan kajian lampau terhadap bahasa yang dikaji turut memberikan gambaran awal kepada pengkaji untuk menghasilkan satu kajian baru dan menghasilkan pendeskripsian yang lebih berpada. Permasalahan penghuraian kajian awal varian Minangkabau (VM) yang telah dilaksanakan oleh pengkaji lepas umumnya hanya melihat pemetaan geografi kawasan liputan varian Minangkabau sahaja.

Penulisan tentang bahasa Minangkabau pada abad ke-19 dimulakan dengan penerbitan buku cerita pendek dalam tulisan rumi/Latin. Kemudian, ia diteruskan dengan penerbitan pelbagai buku Sastera seperti pantun, susunan beberapa teka teki dan peribahasa. Jelas di sini bahawa kajian awal tentang bahasa Minangkabau lebih menjurus kepada penghasilan bahan bacaan untuk tatapan masyarakat di samping memperkenalkan bahasa Minangkabau ini kepada orang luar bagi mempelajarinya. Walaupun pada awalnya ada kontroversi berkenaan penulisan dalam teks menggunakan tulisan Jawi dan tulisan Rumi namun keadaan ini dapat ditangani dengan penghasilan karya sastera yang bermutu. Sementara itu, kajian bahasa Minangkabau diperhebat lagi dengan penulisan pelopor kajian Minangkabau ini iaitu J.L. van der Toorn yang mencipta transkripsi bahasa Minangkabau. Beliau telah menerbitkan cerita dongeng dan legenda Mandjau Ari dan Tjindoer Mato kedua-duanya pada tahun 1891. Penulis berpendapat dengan adanya penghasilan karya sastera sebegini ia dapat mengembangkan lagi bahasa Minangkabau ini kepada masyarakat daripada kaum-kaum lain.

Melalui buku Tatabahasa Minangkabau yang diusahakan oleh Gerard Moussay (1981) diperjelaskan keterangan tentang susunan bahasa yang betul berkenaan bahasa Minangkabau. Penjelasan Moussay (1981) mencakupi aspek fonologi, satuan makna dan juga struktur ayat. 
Selain itu, beliau juga menghuraikan aspek frasa nama dan frasa verbal agar mereka yang ingin mempelajari bahasa ini mampu menguasai bahasa Minangkabau dengan baik. Nadra (2006) meneliti dengan melakukan rekonstruksi bahasa Minangkabau. Kajian yang dilakukan dengan mengamati titik pemetaan kawasan dialek Minangkabau ini tersebar di Sumatera Barat. Kajian ini dapat memberikan maklumat variasi dialek Minangkabau itu sendiri. Nadra telah memberikan penjelasan bahawa daripada kajiannya didapati unsur fonologi bahasa Minangkabau di Sumatera Barat dikelompokkan kepada 16 dialek, morfologi kepada 39 dialek dan akhirnya leksikal kepada 7 kawasan dialek. Nadra juga menyatakan bahawa yang terhasil melalui pemecahan unsur fonologi dan morfologi tadi hanyalah keanekaragaman dialek semata-mata. Bagi pengelompokan dialek taburan yang besar seperti unsur fonologi dan morfologi tidak boleh digunakan. Oleh itu, unsur leksikal yang mempunyai taburan di tujuh kawasan sahaja yang boleh digunakan.

Penulis berpendapat bagi bidang dialektologi ia telah menepati kerana melihat variasi dialek yang terhasil kesan daripada titik pemetaan yang dilakukan. Tambahan pula, Nadra juga melakukan rekonstruksi bahasa Minangkabau. Namun, Nadra belum membuat klasifikasi dalam bahasa Minangkabau purba. Penulis bercadang untuk meneruskan lagi kajian ini hingga menghasilkan klasifikasi bahasa Minangkabau Purba. Sementara itu, Medan (1986) dan Maksan (1984) telah menggunakan data yang sama dalam penelitian mereka berkaitan dengan geografi dialek kawasan masing-masing. Medan meninjau kawasan Pasaman, manakala Maksan di kawasan Persisir Selatan. Daftar pertanyaan 585 leksikal dan 109 morfologi digunakan dalam kajian mereka ini. Hasil kajian dari Maksan mendapati bahasa Minangkabau di daerah Persisir Selatan dibahagikan kepada dua kawasan dialek iaitu di Pancung Soal dan Kubuang Tigo Baleh. Manakala kajian Medan pula memperoleh empat kawasan dialek yang dibezakan iaitu dialek Pasaman, dialek Sinurut, dialek Rao Talu dan dialek Mapat Tunggul.

Hasil kajian mereka menunjukkan wujudnya perbezaan yang banyak tentang variasi Minangkabau ini di Sumatera Barat. Walaupun kajian mereka telah lama diterbitkan, namun ia masih boleh dibuat penambahbaikan dengan melihat pula unsur fonologi sama ada banyak perubahan atau sebaliknya. Penulis berpendapat kajian mereka ini boleh diteruskan dengan melihat unsur retensi dan inovasi daripada data yang diperoleh mereka bagi membuat rekonstruksi dan klasifikasi bahasa Minangkabau purba. Hal ini jelas daripada teori yang diaplikasikan oleh Medan (1986) yang menggunakan juga teori linguistik struktural, dialektologi dan linguistik komparatif (Raimo, Anttilo) dalam kajian yang dijalankan. Menurut Medan, teori linguistik komparatif digunakan untuk mencari hubungan variasi unsur-unsur fonetik yang ditentukan. Medan hanya menggunakan teori ini untuk melihat pengelompokan variasi-variasi dan titik pemetaan bagi melihat perkaitan antara satu sama lain.

Kajian dari sudut sosiolinguistik pula dijalankan oleh Media Sandra Kasih (2004). Beliau berjaya menghasilkan konsep kata sapaan dalam kalangan masyarakat umum mahupun masyarakat kelas atasan. Konsep sapaan yang ditelusuri oleh Media ini mampu menyumbang kepada masyarakat Minangkabau itu sendiri. Hal ini jelas dapat dilihat apabila beliau menjelaskan bagaimana golongan atasan (adat) dalam masyarakat Minang ini disapa oleh rakyat biasa. Penggunaan gelaran seperti Datuak, Bagindo, Sutan dan sebagainya diperjelaskan dan hal ini mampu memberikan pedoman kepada masyarakat umum untuk berkomunikasi dengan lebih baik dalam bersosial.

Jufrizal (2004) pula membicarakan persoalan bahasa Minangkabau ragam adat yang mengalami 'pengeringan' atau pelupusan akibat daripada pelbagai faktor termasuklah kesan daripada ledakan teknologi, politik mahupun perubahan pandangan hidup. Jufrizal mendapati terdapatnya pelupusan bahasa Minang yang indah-indah dalam pengucapan seharian mahupun 
dalam mesyuarat pemilihan anggota surau di kawasan kajiannya. Seharusnya bahasa Minangkabau ragam adat ini ditandai dengan intonasi dan gaya bahasa yang ada kiasan, pantun, seni dan adat mengikut situasi dan tempat. Namun, berdasarkan kajian Jufrizal berlaku 'pengeringan' atau pelupusan sedikit demi sedikit nilai estetika bahasa Minangkabau ragam adat ini dalam kajian yang dilakukan.

Jufrizal merujuk kepada Labov (1994) bahawa prinsip-prinsip perubahan bahasa disebabkan beberapa faktor, antaranya:

i. Faktor dalaman. Faktor ini berkenaan dengan waktu kemunculan dan waktu kenyataan. Dalam hal ini ia berkaitan dengan perubahan suara, penyatuan dan pengaruh fungsional.

ii. Faktor sosial. Ini adalah masalah penempatan sosial dalam pembaharuan, pengaruh suku kaum dan ras kepada perubahan dan motivasi sosial perubahan tersebut.

iii. Faktor kognitif. Antara faktornya ialah pengaruh perubahan pada pemahaman dalam dialek, prinsip perubahan sintaksis dan tatabahasa.

Kenyataan Labov ini menyokong lagi kebenaran kajian Jufrizal kerana berlakunya kemusnahan sedikit demi sedikit keindahan berbahasa dalam bahasa Minangkabau itu sendiri. Keadaan seperti ini tidak boleh dibiarkan berlaku. Seharusnya ada usaha untuk mengatasi masalah ini daripada terus berlaku. Pada pendapat penulis situasi kemusnahan keindahan dalam berbahasa ini bukan hanya terdapat dalam kalangan penutur Minang, penutur bahasa lain seperti bahasa Melayu juga mengalami situasi yang sama. Adalah amat merugikan jika perkara sedemikian tidak ditangani dengan sebaik mungkin. Bimbang generasi akan datang tidak mengenali lagi bagaimana memperindah bahasa dalam ayat dan pertuturan.

Selanjutnya, Jane Drakard (1999) membincangkan persoalan bahasa dan kebesaran dalam masyarakat Minangkabau. Penggunaan bahasa yang halus dan santun digunakan bagi menunjukkan rasa hormat dari seseorang kepada orang yang berpangkat dalam sistem sosial masyarakat. Jika dilihat melalui penulisan surat, dijumpai permulaan penulisan surat akan ditulis dengan kalimah yang suci pujian kepada Allah yang maha esa. Petikan ayat al-Quran juga disertakan melambangkan agama anutan masyarakat Minang ini begitu suci dan penganutnya mentaati ajaran agamanya. Hal ini jelas melalui petikan berikut: "Arabic phrases and quotations form the Qur'an affirmed the sacred source and quality of the ruler's words, a message which was repeated in many ways within the letters" (Drakard, 1999: 233). Penggunaan bahasa yang halus dan sopan perlu diteruskan dan dikembangkan dalam persuratan Melayu agar kita tidak lupa jati diri kita sebagai bangsa yang memiliki keindahan berbahasa. Penulis dapat kaitkan dengan penggunaan bahasa semasa temu bual yang dijalankan, informan yang penulis temui begitu menitikberatkan pertuturan yang lebih sopan dan berhalus dalam perbincangan.

Selanjutnya, kajian Edward Djamaris (1984) yang menulis tentang bahasa Melayu Minangkabau. Beliau mengkaji teks sastera seperti Hikayat Muhamad Hanafiah, Hikayat Banjar dan Hikayat Acheh. Daripada kajian yang dilakukan, Edward menemui persamaan dan perbezaan antara bahasa Melayu dan bahasa Minangkabau dalam teks sastera yang dikajinya. Terdapat pengaruh bahasa Minangkabau dalam teks yang diteliti. Penulis juga mengakui bahawa bahasa Minangkabau banyak persamaan dengan bahasa Melayu daripada segi ejaan dan yang membezakannya adalah beberapa sebutan. Oleh yang demikian, melalui kajian yang penulis ingin teruskan yakni membuat klasifikasi bahasa Minangkabau purba penulis merasakan dengan adanya kajian Djamaris memberikan lebih maklumat tentang pengaruh bahasa Melayu dalam bahasa Minangkabau.

Akhirnya, kajian tentang hubungan kekerabatan bahasa Minang dan bahasa sakai yang dilakukan oleh Efri (2008). Kajian beliau ini agak menarik kerana diterbitkan dalam bentuk blog 
di Internet. Berdasarkan kajian yang dibuat, didapati perkataan dalam bahasa Sakai dan bahasa Minang ada jalinan hubungan kekerabatan. Hal ini kerana terdapat banyak persamaan dalam perkataan yang disenaraikan. Oleh itu, memang jelas dan nyata bahawa bahasa Sakai dan bahasa Minang ini datangnya daripada rumpun bahasa yang sama. Walau bagaimanapun, penulis tidak bersetuju dengan kenyataan Efri yang menyatakan pendekatan linguistik sejarawi digunakan dalam kajiannya. Hal tersebut kerana melalui pembacaan penulis daripada artikel tidak terdapat unsur rekonstruksi dan klasifikasi dalam kajian. Oleh itu, kajian Efri (2008) ini tidak tergolong dalam bidang linguistik sejarawi. Penulis telah mengulas berkenaan kajian lepas berkenaan kajian bahasa Minangkabau. Walaupun tidak menjurus secara langsung kepada bidang linguistik bandingan, namun dengan adanya sorotan kajian lepas ini memberikan maklumat dan gambaran tentang perkembangan kajian bahasa Minangkabau dari dahulu hingga sekarang.

\section{Metodologi kajian}

Kajian ini menggunakan reka bentuk etnografi, yakni memberi fokus kepada kajian suku etnik Minangkabau yang wujud di Sumatera dan di Semenanjung Malaysia. Pendekatan kajian adalah kualitatif dengan memberi fokus kepada pemerian varian dialek yang dituturkan oleh etnik Minangkabau yang berada di dua lokasi geografi tersebut. Pengumpulan data menggunakan metode semak dan cakap melalui teknik temu bual terarah dan bebas, teknik perakaman, teknik pengajuan gambar dan teknik pencacatan. Data varian Minangkabau yang diperoleh ditranskripsikan menggunakan sistem abjad fonetik antarabangsa (IPA). Analisis data menggunakan tata cara linguistik bandingan historis melalui penentuan kata kognat, menentukan perangkat korespondensi fonem, penentuan rekerensi fonem atau pengulangan fonem, dan akhir sekali penentuan fonem purba. Proses pemaparan data menggunakan jadual, dan rajah di samping menggunakan terminologi khusus dalam ilmu linguistik bandingan. Di samping itu juga, lambanglambang khas dalam ilmu ini juga dimanfaatkan, misalnya lambang fonem / /, lambang * yang menunjukkan bentuk fonem purba, lambang : menggambarkan 'sepadan', lambang [ ] bererti 'bunyi', dan lambang > bererti 'menjadi'.

\section{Pendekatan Kajian}

Untuk mencapai matlamat rekonstruksi ini, fonem-fonem BMP dipaparkan dengan menggunakan kaedah rekonstruksi dalaman (internal reconstruction). Dalam kajian Mohammed Tarmizi, Rahim dan Shahidi (2014), kaedah rekonstruksi ini juga diterapkan. Selain itu, bentuk kata purba BMP turut dipaparkan seiring dengan rekonstruksi fonem-fonem tersebut. Selanjutnya, kaedah merekonstruksi sesuatu bahasa purba memiliki kriteria seperti berikut (Crowley, 1992; Campbell, 2001; Ringe \& Eska, 2013);

i. menentukan kata-kata kognat daripada beberapa bahasa turunan yang dijadikan bahasa bandingan. Jika kata-kata kognat itu tidak diperoleh atau memiliki bentuk yang sama sekali berbeza, maka ini bermakna kata tersebut mungkin diturunkan daripada sumber bahasa purba yang lain. Jika kata-kata yang dibandingkan itu berkognat, maka kita harus menentukan darjat kesamaan bentuk dan maknanya. Berkaitan hal ini, Crowley (1992, hlm. 92) mengatakan, "...If they are similar enough that it could be assumed that they are derived from a single original form with single original meaning...". Perlu dijelaskan juga bahawa penentuan kata-kata kognat dilakukan setelah kata yang menunjukkan kesamaan bentuk-makna yang disebabkan oleh faktor kebetulan, pinjaman, dan ikonik diasingkan 
terlebih dahulu.

ii. Menyusun set-set koresponden bunyi bahasa yang dibandingkan itu. Dengan menggunakan data dalam Jadual 1, maka perangkat korespondensi bunyi dapat diperoleh seperti berikut;

Jadual 1. Kata kognat empat bahasa kepulauan Pasifik.

\begin{tabular}{lcccc}
\hline Tongan & $\mathrm{t}$ & $\mathrm{a}$ & $\mathrm{p}$ & $\mathrm{u}$ \\
Samoan & $\mathrm{t}$ & $\mathrm{a}$ & $\mathrm{p}$ & $\mathrm{u}$ \\
Rarotongan & $\mathrm{t}$ & $\mathrm{a}$ & $\mathrm{p}$ & $\mathrm{u}$ \\
Hawai & $\mathrm{k}$ & $\mathrm{a}$ & $\mathrm{p}$ & $\mathrm{u}$ \\
\hline \multicolumn{2}{l}{ Sumber: Crowley (Rahim, 2008: 28) }
\end{tabular}

Terdapat empat koresponden seperti mana dalam Jadual 1, iaitu koresponden pertama; Tongan /t/, Samoan /t/, Rarotongan /t/ dan Hawai /k/. Koresponden kedua, ketiga dan keempat semua bahasa menunjukkan /a/, /p/ dan /u/. Keempat-empat peringkat koresponden tersebut dapat dituliskan seperti dalam Jadual 2.

Jadual 2. Perangkat koresponden empat bahasa kepulauan Pasifik.

\begin{tabular}{cccc}
\hline Tongan & Samoan & Rarotongan & Hawai \\
\hline $\mathrm{t}:$ & $\mathrm{t}:$ & $\mathrm{t}:$ & $\mathrm{k}$ \\
$\mathrm{a}:$ & $\mathrm{a}:$ & $\mathrm{a}:$ & $\mathrm{a}$ \\
$\mathrm{p}:$ & $\mathrm{p}:$ & $\mathrm{p}:$ & $\mathrm{p}$ \\
$\mathrm{u}:$ & $\mathrm{u}:$ & $\mathrm{u}:$ & $\mathrm{u}$ \\
\hline
\end{tabular}

Sumber: Crowley (Rahim, 2008: 28)

Set perangkat korespondensi ini perlu dilakukan pada semua kata yang telah disenaraikan sebagai kognat. Menentukan fonem purba daripada setiap set perangkat korespondensi atau perangkat kesepadanan. Bagi setiap set perangkat korespondensi bunyi tadi, kita perlu menentukan fonem purba, iaitu fonem yang dianggap menurun perangkat set korespondensi fonemis yang berlaku dalam bahasa-bahasa turunan tersebut. Satu set perangkat korespondensi fonemis hanya menurunkan satu sahaja fonem purba. Selanjutnya apabila satu set perangkat korespondensi telah ditentukan, langkah seterusnya ialah memastikan set perangkat korespondensi tadi wujud dalam pasangan kata yang lain pula. Hal ini bererti adanya rekurensi fonemik (phonemic recurrence). Usaha penentuan sesuatu fonem purba tidaklah begitu mudah. Dalam melakukan rekonstruksi fonem beberapa prinsip berikut perlu diperhatikan. Menurut Rahim (2008: 29), beberapa prinsip tersebut adalah:

i. Rekonstruksi mesti melihat kepada perubahan bunyi yang bersifat munasabah, yakni satu perubahan bunyi yang umumnya berlaku pada semua bahasa dunia.

ii. Sebuah fonem yang distribusinya paling banyak dalam bahasa-bahasa turunan dapat dianggap sebagai pantulan linear daripada fonem purba.

iii. Rekonstruksi mesti mengisi ruang kosong dalam sesuatu sistem fonologi suatu bahasa daripada mencipta satu sistem fonologi yang tidak seimbang dalam bahasa tersebut.

iv. Sebuah fonem purba tidak boleh direkonstruksi sehingga fonem tersebut betul- betul wujud dan dapat dibuktikan dalam bahasa-bahasa turunan.

Oleh itu, berdasarkan pendekatan rekonstruksi yang telah diutarakan oleh Crowley (1992) dan Campbell (2001), rekonstruksi fonem vokal bahasa Minangkabau Purba (BMP) dapat dilakukan. 


\section{Data dan perbincangan}

Fonem vokal dan diftong VMP yang diperbahaskan dalam penulisan ini ialah hasil daripada rekonstruksi fonem yang telah dibuat terhadap enam belas VM yang meliputi lokasi geografi yang berbeza lokasinya iaitu di Bangkinang (BKG), Paya Kumbuh (PK), varian Tanah Datar (TD), varian Rao (RAO), varian Pancung Soal (PS), varian Pangkalan Koto Baru (PKB), varian Agam Barat (AGB), varian Agam Timur (AGT), varian Muara Sg. Labuh (MSL), varian Pariaman (PRMN) di Pulau Sumatera. Di Semenanjung Malaysia, kajian dibuat di Negeri Sembilan di Kg. Gagu Jelebu (KGJ) dan Kg. Talang Kuala Pilah (KTKP), Selangor di Kg. Padang Hulu Langat (KPHL) dan Kg. Ulu Rening Batang Kali (KUR), Kg. Sesapan Batu Minangkabau, Beranang dan Pahang di Kg. Janda Baik Bentong (KJB). Selanjutnya, hasil daripada rekonstruksi yang telah dilakukan membuktikan bahawa jumlah inventori dan distribusi fonem vokal dan diftong BMP ialah seperti yang terdapat dalam huraian berikut. Penyebaran fonem VMP ini memperlihatkan keberadaan fonem dan bunyi fonem vokal dan diftong BMP ini berdasarkan posisinya sama ada pada posisi awal, tengah/antarvokal atau akhir dalam perkataan.

\section{Rekonstruksi Vokal VMP}

Berdasarkan perangkat kesepadanan terhadap 200 perkataan yang telah direkonstruksi, penulis mendapati VMP memiliki 6 fonem iaitu $/ *_{\mathrm{i}}, *_{\mathrm{u}}, *_{\mathrm{o}}, *_{\mathrm{e}}, *_{\leftrightarrow} \leftrightarrow$ dan $* \mathrm{a} /$ yang terdiri daripada satu vokal depan, dua vokal tengah, dan dua vokal belakang. Inventori fonem vokal VMP ini dapat dilihat dalam Jadual 3.

Jadual 3. Inventori vokal VMP.

\begin{tabular}{cccc}
\hline Bahagian & Depan & Tengah & Belakang \\
Kedudukan & & & \\
\hline Tinggi & $* \mathrm{i}$ & & $*_{\mathrm{u}}$ \\
Separuh Tinggi & $* \mathrm{e}$ & $* \leftrightarrow$ & \\
Separuh Rendah & & $*_{\mathrm{a}}$ & \\
Rendah & & & \\
\hline
\end{tabular}

\section{Rekonstruksi vokal depan VMP *i dan *e}

Vokal /i/ boleh hadir pada semua posisi kata iaitu posisi awal kata, tengah kata, suku kata terbuka dan suka kata tertutup dalam semua VM. Manakala vokal *e hanya boleh hadir di posisi suku kata terbuka dan suku kata tertutup. Perkara ini dapat dilihat melalui Jadual 4 dan 5.

Melalui Jadual 4, didapati vokal /i/ hadir pada semua posisi kata yakni /i/ hadir pada awal kata, suku kata terbuka, suku kata pra akhir dan suku kata akhir tertutup. Misalnya pada awal kata [kida] iaitu kiri dalam bahasa Melayu standard. Menurut Adelaar (1985: 68), kebiasaannya vokal /i/ mempunyai /i/ dan /ie/ dalam silabel akhir. Contohnya dalam perkataan putih yang menjadi putieh apabila dibandingkan antara Minang dengan bahasa standard. Manakala Jadual 5 menunjukkan penyebaran vokal *e dalam varian Minangkabau. Melalui Jadual 5, didapati bahawa vokal *e hanya hadir pada suku kata terbuka dan suku kata tertutup sahaja, pada antara vokal e tidak hadir. 
Jadual 4. Refleks VMP $*$ i dalam 16 VM.

\begin{tabular}{|c|c|c|}
\hline $\begin{array}{l}\text { Vokal } \\
\text { VMP }\end{array}$ & $\begin{array}{l}\text { Penyebaran } \\
\text { Pada Posisi }\end{array}$ & Contoh Refleks VMP *i Dalam 16 VM \\
\hline \multirow[t]{5}{*}{$* \mathrm{i}$} & Awal Kata & 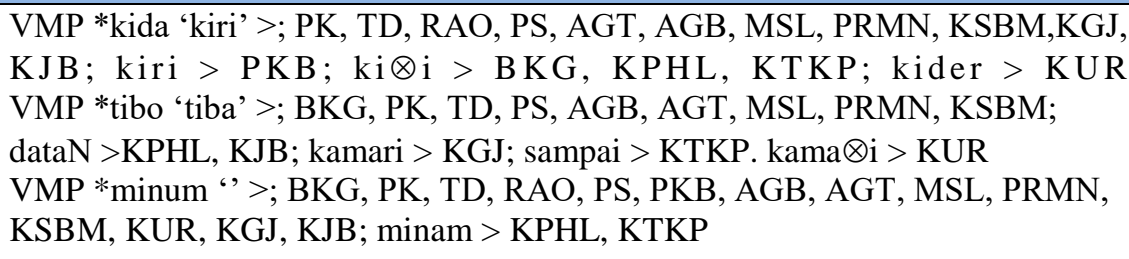 \\
\hline & $\begin{array}{l}\text { Suku Kata } \\
\text { Terbuka }\end{array}$ & $\begin{array}{l}\text { VMP *dZa } \otimes \mathrm{i} \text { ‘jari’ > BKG, PK, PS, MSL, PRMN, KPHL, KUR, KTKP; dZari } \\
>\text { TD, RAO, PKB, AGB, AGT, KSBM, KGJ, KJB. }\end{array}$ \\
\hline & $\begin{array}{l}\text { Suku Kata } \\
\text { Praakhir }\end{array}$ & $\begin{array}{l}\text { VMP *balio/ 'balik kembali' > BKG; balia/ > PK, TD, PKB, AGT, AGB, MSL, } \\
\text { PRMN, KPHL, KSBM, KGJ; poe > RAO; lia/ > PS; pulaN > } \\
\text { KUR, KJB; bali/ > KTKP }\end{array}$ \\
\hline & \multirow[t]{2}{*}{$\begin{array}{l}\text { Suku Kata } \\
\text { Akhir } \\
\text { Tertutup }\end{array}$} & $\begin{array}{l}\text { VMP *batih 'betis' > TD, RAO, AGB, AGT, PRMN, KSBM, KGJ, KJB; boti > } \\
\text { BKG, PK, PKB, KUR, KTKP. }\end{array}$ \\
\hline & & $\begin{array}{l}\text { VMP *kabui/ 'debu' > TD, PS, PKB, AGT, AGB, PRMN; abou/ > BKG, KUR; } \\
\text { abu>PK, RAO, MSL,KSBM; abua/ > KGJ, KJB. }\end{array}$ \\
\hline
\end{tabular}

Jadual 5. Refleks VMP *e dalam 16 VM.

\begin{tabular}{lll}
\hline $\begin{array}{l}\text { Vokal } \\
\text { VMP }\end{array}$ & $\begin{array}{l}\text { Penyebaran } \\
\text { Pada Posisi }\end{array}$ & Contoh Refleks VMP *i Dalam 16 VM \\
\hline$*_{\mathrm{e}}$ & $\begin{array}{l}\text { Suku Kata } \\
\text { Terbuka }\end{array}$ & $\begin{array}{l}\text { VMP *lope 'lepas' >; BKG, PK; lopeh > RAO; lapeh > TD, AGT, AGB, } \\
\text { PRMN, KUR; lape > KPHL; ditaNgalan > PS; malapeh > KJB }\end{array}$ \\
& $\begin{array}{l}\text { Suku Kata } \\
\text { Tertutup }\end{array}$ & VMP *ce $\otimes$ e/ 'cerek' > BKG, PK, PKB, MSL, PRMN, KPHL, KUR, \\
& $\begin{array}{l}\text { KTKP; cere/ > TD, RAO, PS, KSBM, KJB; kumbuo/ > AGB; kumbua/ > } \\
\text { AGT } \\
\end{array}$ & VMP *pepe/ 'kemaluan perempuan' > TD, RAO, AGT, KTKP, KJB; \\
& ompo/ > BKG; cepa/ > PS; ampe/ > PKB; opo/ > AGB; ume/ > MSL; \\
& pante/ > PRMN, KPHL, KSBM, KGJ; cune/ > KUR \\
&
\end{tabular}

\section{Rekonstruksi vokal belakang VMP *u dan *o}

Vokal u boleh hadir pada semua posisi dalam VM iaitu awal kata, suku kata praakhir, suku kata akhir dan suku kata tertutup. Vokal VMP *u pada posisi suku kata praakhir hadir sebagai [ua] atau [ui], misalnya dalam perkataan bendul yang menjadi bandua dalam beberapa VM seperti yang penulis letakkan dalam Jadual 6 dan 7.

Berdasarkan Jadual 7, didapati vokal /o/ hadir pada awal kata, suku kata terbuka, suku kata praakhir dan suku kata akhir tertutup. Hal ini jelas melalui contoh data yang diperoleh seperti perkataan /ato// yang mana hampir kesemua kawasan yang dikunjungi pengkaji menuturkan perkataan sedemikian, kecuali KTKP yang menyatakan /atap/ sebagai /atap/. 
Jadual 6. Refleks VMP *u dalam 16 VM

\begin{tabular}{|c|c|c|}
\hline $\begin{array}{l}\text { Vokal } \\
\text { VMP }\end{array}$ & $\begin{array}{l}\text { Penyebaran } \\
\text { Pada Posisi }\end{array}$ & Contoh Refleks VMP *u Dalam 16 VM \\
\hline \multirow[t]{5}{*}{$* \mathrm{u}$} & Awal Kata & $\begin{array}{l}\text { VMP *puse/ 'pusat' >; BKG, PK, TD, RAO, PS, PKB, AGT, AGB, MSL, PRMN, } \\
\text { KPHL, KSBM, KUR, KGJ, KTKP, KJB }\end{array}$ \\
\hline & $\begin{array}{l}\text { Suku Kata } \\
\text { Terbuka }\end{array}$ & $\begin{array}{l}\text { VMP *pintu ' > BKG, PK, TD, RAO, PS, PKB, AGT, AGB, MSL, PRMN, } \\
\text { KPHL, KSBM, KUR, KGJ, KTKP, KJB }\end{array}$ \\
\hline & $\begin{array}{l}\text { Suku Kata } \\
\text { Praakhir }\end{array}$ & $\begin{array}{l}\text { VMP *padusi 'perempuan'> TD, PKB, AGB, AGT, MSL, PRMN, KPHL, KSBM, } \\
\text { KGJ, KJB; batino > KTKP, KUR, PS, PK, BKG; podusi > RAO }\end{array}$ \\
\hline & $\begin{array}{l}\text { Suku Kata } \\
\text { Akhir Tertutup }\end{array}$ & $\begin{array}{l}\text { VMP* bandua 'bendul' > AGT, AGB, PRMN, KUR, KGJ, TD; bondua > BKG, } \\
\text { PK; langkan >PS; bandu } \leftrightarrow \text { KPHL, KSBM; bandu>MSL; bandui > KJB; } \\
\text { bondu } \leftrightarrow>\text { PKB; bandul > KTKP }\end{array}$ \\
\hline & & VMP*buruoN 'burung’>RAO, PS, PKB, KSBM, KJB, bu $\otimes_{\mathrm{oN}}$ \\
\hline
\end{tabular}

Jadual 7. Refleks VMP *o dalam 16 VM

\begin{tabular}{lll}
\hline $\begin{array}{l}\text { Vokal } \\
\text { VMP }\end{array}$ & $\begin{array}{l}\text { Penyebaran } \\
\text { Pada Posisi }\end{array}$ & Contoh Refleks VMP *u Dalam 16 VM \\
\hline$*_{0}$ & Awal Kata & $\begin{array}{l}\text { VMP *oma/ 'ibu' > PKB, KUR, KTKP; ama/ > BKG, PK, TD, PS, AGT, AGB, } \\
\text { M S L, P R M N , K P H L, K S B M, K G J, K J B ; u m a / > R A O }\end{array}$ \\
& & \\
& $\begin{array}{l}\text { Suku Kata } \\
\text { Terbuka }\end{array}$ & VMP *balaNo > 'periuk' > BKG, TD, PS, PKB, MSL, PRMN, KPHL, KSBM, \\
& KUR, KGJ, KTKP, KJB; pi®uo/ > PK; poriu/ > RAO; pariyua/ > AGB, AGT \\
& Suku Kata & VMP *iduoN 'hidung' > BKG, PK, RAO, PS, PKB, AGB, AGT, KPHL; iduaN> \\
& Praakhir & TD, AGT, MSL, PRMN, K SBM, KUR, KGJ, KJB; idu N > KT KP \\
& Suku Kata & VMP* ato/ 'atap' > BKG, PKB, TD, RAO, PS, PKB, AGB, AGT, MSL, PRMN, \\
& Akhir Tertutup & KPHL, KSBM, KUR, KGJ, KJB; atap > KTKP \\
\hline
\end{tabular}

\section{Rekonstruksi vokal separuh rendah tengah $* \leftrightarrow$}

Vokal $* \leftrightarrow$ hanya boleh hadir pada dua posisi kata sahaja iaitu pada suku kata terbuka dan suku kata awal dalam VM. Situasi ini dapat dilihat dalam Jadual 8. Jadual 8 menunjukkan keberadaan vokal $* \leftrightarrow$ yang hanya hadir pada posisi awal kata dan suku kata terbuka. Misalnya pada perkataan

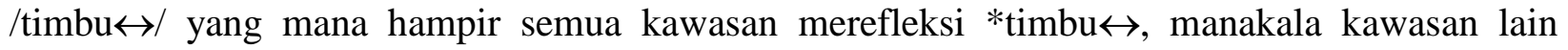
direfleksi sebagai 'mancogo', dan 'mampuoN'.

Jadual 8. Refleks VMP $* \leftrightarrow$ dalam 16 VM

\begin{tabular}{|c|c|c|}
\hline $\begin{array}{l}\text { Vokal } \\
\text { VMP }\end{array}$ & $\begin{array}{l}\text { Penyebaran } \\
\text { Pada Posisi }\end{array}$ & Contoh Refleks VMP $* \leftrightarrow$ Dalam 16 VM \\
\hline \multirow[t]{2}{*}{$* \leftrightarrow$} & Awal Kata & $\begin{array}{l}\text { VMP *k↔tia/ 'ketiak'> KTKP; katia/ > PK, TD, PD, PKB, AGB, AGT, MSL, } \\
\text { PRMN, KPHL, KSBM, KGJ, KJB; kutia/ > BKG, KUR; kotia/ > RAO }\end{array}$ \\
\hline & $\begin{array}{l}\text { Suku Kata } \\
\text { Terbuka }\end{array}$ & $\begin{array}{l}\text { VMP *timbu } \leftrightarrow \text { 'timbul' > BKG, TD, AGB, AGT, PRMN, KPHL, KUR, } \\
\text { KGJ, } \\
\text { KJB; mampuoN >PK; mancogo > PS; mampalia/ >MSL; timbul > KTKP }\end{array}$ \\
\hline
\end{tabular}




\section{Rekonstruksi vokal rendah tengah *a}

Vokal *a boleh hadir pada semua posisi dalam VM iaitu awal kata, suku kata praakhir, suku kata akhir dan suku kata tertutup. Vokal VMP *a boleh dilihat melalui contoh data yang dipapar dalam Jadual 9. Berdasarkan Jadual 9, menunjukkan yang vokal *a hadir pada semua posisi kata misalnya pada perkataan /liyia/ atau /leher/. Perkataan /liyia/ hadir pada semua varian kecuali pada varian MSL yang memanggil /leher/ sebagai /mayia/ dan varian PKB yang memanggil /leher/ sebagai /tiliyiu/.

Jadual 9. Refleks VMP *a dalam 16 VM.

\begin{tabular}{|c|c|c|}
\hline $\begin{array}{l}\text { Vokal } \\
\text { VMP }\end{array}$ & $\begin{array}{l}\text { Penyebaran } \\
\text { Pada Posisi }\end{array}$ & Contoh Refleks VMP *u Dalam 16 VM \\
\hline \multirow[t]{4}{*}{ *a } & Awal Kata & $\begin{array}{l}\text { VMP *andZiaN 'anjing' > PK, TD, PS, AGT, AGB, MSL, PRMN, KSBM, KUR, } \\
\text { KGJ, KJB; andZioN> BKG, PKB, KPHL; andZeN> RAO; andZiN> KTKP }\end{array}$ \\
\hline & $\begin{array}{l}\text { Suku Kata } \\
\text { Terbuka }\end{array}$ & $\begin{array}{l}\text { VMP *liyia 'leher' > TD, PS, AGT, AGB, PRMN, KGJ, KJB; } \leftrightarrow \leftrightarrow \text { toliu > BKG; } \\
\text { mo } \otimes \text { ieh > PK; lihia> RAO, KPHL, KSBM, KUR; taliyiu> PKB; mayia > MSL; } \\
\text { lehe > KTKP }\end{array}$ \\
\hline & $\begin{array}{l}\text { Suku Kata } \\
\text { Praakhir }\end{array}$ & $\begin{array}{l}\text { VMP *balakaN 'belakang' > BKG, PS, PKB, AGB, AGT, PRMN, KUR, KTKP; } \\
\text { puNguaN> TD, KSBM, KGJ; bolaka > RAO; tulang belike/ > KPHL; kuduo/ } \\
\text { KJB }\end{array}$ \\
\hline & $\begin{array}{l}\text { Suku Kata } \\
\text { Akhir Tertutup }\end{array}$ & $\begin{array}{l}\text { VMP* piNgaN'pinggang' > BKG, PK, TD, RAO, PS, PKB, AGB, AGT, MSL, } \\
\text { PRMN, KPHL, KSBM, KUR, KGJ, KTKP, KJB } \\
\text { VMP *raNgah 'balung ayam' > AGT, AGB, KSBM, KGJ, KJB; piea > BKG, } \\
\text { PKB, aNgah > PK, PRMN; kapalo > RAO; piau, KUR, PKB, MSL; baluoN > } \\
\text { KPHL, KTKP }\end{array}$ \\
\hline
\end{tabular}

Berdasarkan pemaparan data 2 di atas didapati vokal /i/ hadir pada semua posisi kata. Hal ini menepati kajian sebelum ini seperti yang pernah dijalankan oleh Adelaar (1992) yang juga memperlihatkan bahawa vokal /i/ ini memberi refleks pada penyebaran semua posisi kata. Penulis mendapati juga wujudnya pengintegrasian data antara kawasan kajian di Sumatera dan Semenanjung iaitu di kawasan Paya Kumbuh, Tanah Datar, Rao, Pancung Soal, Agam Timur dan Agam Barat, Muara Sungai Labuh, Pariaman di Sumatera dan kawasan Kg Sesapan Batu Minangkabau, Kg Gagu Jelebu, dan Kg. Janda Baik yang mana memiliki refleks kata *kida untuk perkataan kiri dalam bahasa Melayu standard. Walau bagaimanapun, di kawasan lain seperti di Bangkinang Sumatera dan Kg Padang Hulu Langat dan Kg Talang Kuala Pilah penulis mendapati penduduk di sana menggunakan perkataan ki $\otimes \mathrm{i}$ untuk /kiri/ dan yang akhirnya kawasan Kg Ulu Rening memanggil 'kider' untuk/kiri/.

Sementara itu, melalui data seterusnya bagi vokal /u/ penulis mendapati ia juga hadir pada semua posisi kata dan ini jelas melalui contoh data suku kata praakhir iaitu *padusi 'perempuan' untuk kawasan Sumatera dan Semenanjung. Kata *padusi digunakan di kawasan Tanah Datar, Pangkalan Koto Baru, Agam Barat, Agam Timur, Muara Sungai Labuh, Pariman manakala di Semenanjung digunakan di Kg Sesapan Batu Minangkabau, Kg Gagu Jelebu dan Kg. Janda Baik. Sementara kawasan lain memanggil /batino/ di Pancung Soal, Paya Kumbuh, Bangkinang di Sumatera manakala di Semenanjung di Kg Talang Kuala Pilah, Kg. Ulu Rening. Hanya satu kawasan di Rao Sumatera menggunakan kata /podusi/ untuk memanggil perempuan. 
Selanjutnya, data melalui vokal /o/ yang memperlihatkan pengintegrasian kawasan sebutan kata *ato? untuk perkataan atap yang sama antara Sumatera dan Semenanjung iaitu di kawasan Bangkinang, Pangkalan Koto Baru, Tanah Datar, Rao, Pancung Soal, Pangkalan Koto Baru, Agam Barat, Agam Timur, Muara Sungai Labuh dan Pariaman. Manakala di Semenanjung pula adalah di kawasan Kg. Padang Hulu Langat, Kg. Sesapan Batu Minangkabau, Kg. Ulu Rening, Kg. Gagu Jelebu dan Kg. Janda Baik. Hanya satu kawasan sahaja yang menggunakan perkataan yang sama dengan bahasa Melayu standard iaitu 'atap' di kawasan Kg. Talang Kuala Pilah.

Perbincangan data yang terakhir adalah tentang vokal /a/ yang mana ianya juga hadir pada semua posisi kata yakni melalui data *liyia 'leher'. Wujudnya pengintegrasian geopolitik di kawasan Sumatera dan Semenanjung daripada data tersebut iaitu di kawasan Tanah Datar, Pancung Soal, Agam Timur, Agam Barat, dan Pariaman di Sumatera manakala di Semenanjung di kawasan Kg. Gagu Jelebu dan Kg. Janda Baik.

\section{Kesimpulan}

Secara keseluruhannya kajian yang telah dipaparkan dalam penulisan ini adalah kajian terbaharu yang menggunakan metode perbandingan kualitatif yang lebih komprehensif sesuai dengan sifat bahasa yang berubah mengikut tabii. Enam belas VM telah dikaji iaitu BKG, PK, TD, RAO, PKB, AGM, AGT, PS, MSL, PRMN, KPHL, KSBM, KUR, KTKP, KGJ dan KJB. Hasil perbandingan yang dilakukan ke atas enam belas varian Minangkabau ini menghasilkan enam fonem vokal VMP iaitu $*_{\mathrm{i}}, *_{\mathrm{u}}, *_{\mathrm{o}}, *_{\mathrm{e}}, *_{\leftrightarrow} \leftrightarrow$ dan $*_{\mathrm{a}}$. Inovasi yang berbentuk sporadik yang berlaku baik pada fonem vokal yang dipaparkan dalam perbincangan sebelumnya menunjukkan bahawa bentuk inovasi ini bersifat masih baru. Kemungkinan terjadinya inovasi ini kerana faktor migrasi dalaman yang menyebarkan ciri tersebut dalam wilayah yang telah dijadikan lokasi kajian. Hasil daripada rekonstruksi fonem purba yang dilakukan ini, beberapa bentuk kata purba VMP turut diperoleh dan membolehkan pula rekonstruksi yang seterusnya iaitu rekonstruksi leksikal VMP.

\section{Rujukan}

Adelaar K.A. (1992). Proto-Malayic: The reconstruction of its phonology and parts of its morphology and lexicon (Pacific Linguistics C-119). Canberra, Australian National University.

Amat Juhari Moain. (2002). Hubungan Melayu-Minangkabau dari sudut sejarah,bahasa, sastera, budaya, dan masyarakat dalam menelusuri jejak Melayu-Minangkabau. Jakarta, Yayasan Citra Budaya Indonesia.

Arwina Burhanuddin. (1996). Idiom dalam bahasa Minangkabau: Telaah terhadap bentuk dan maknanya. Tesis Universitas Indonesia.

Arwina Burhanuddin. (2002). Perjalanan sejarah Melayu Minangkabau melalui bahasa dalam menelusuri jejak Melayu-Minangkabau. Jakarta, Yayasan Citra Budaya Indonesia.

Asmah Haji Omar. (2001). Kaedah penyelidikan bahasa di lapangan. Kuala Lumpur, Dewan Bahasa dan Pustaka.

Asmah Haji Omar. (2013). Bahasa Minangkabau Mukim Sesapan Batu Minangkabau. Kuala Lumpur, Dewan Bahasa dan Pustaka.

Be Kim Hoa Nio. (1982). Struktur bahasa Minangkabau dialek Lima Puluh Kota, Agam, Tanah Datar, dan Pesisir Selatan. Projek Penelitian Bahasa dan Sastra Indonesia dan Daerah 
Sumatera Barat. Jakarta, Pusat Pembinaan dan Pengembangan Bahasa Departemen P\&K. Collins, J.T. (1981). Ilmu linguistik sejarah: asas, kaedah dan hasilnya. Jurnal Dewan, 5(6), 4550 .

Collins, J.T. (1986). Penyusunan salasilah bahasa Melayu di Malaysia. Bangi, Universiti Kebangsaan Malaysia.

Edward Djamaris (1982). Bahasa Melayu Minangkabau. Jurnal Dewan Bahasa, 6(6), 89-96.

Efri Yoni Baikoeni. (2008). Hubungan kekerabatan bahasa Minang dan bahasa Sakai. http://baikoeni.multiply.com/journal/item/134

Grimes, \& Darrel T. Tyron. (1994). Listing of Austronesian languages. In Darrel T. Tyron (ed.), Comparative Austronesian dictionary: An introduction to Austronesian Studies. Berlin, Mouton de Gruyter.

Haris Abdul Wahab \& Siti Hajar Abu Bakar Ah. (2016). Kaedah penyelidikan kerja sosial pengalaman di lapangan. Kuala Lumpur, Penerbit Universiti Malaya.

Jane Drakard. (1999). A kingdom of words language and power in Sumatra. Kuala Lumpur, Oxford University Press.

Jufrizal. (2004). Bahasa Minangkabau ragam adat: ke arah "Pengeringan" dalam himpitan hegemoni bahasa Indonesia. Linguistik Indonesia, 2(4), 165-178.

Khoo Kay Kim. (1972). The Western Malay States(1850-1873). Kuala Lumpur, Oxford University Press.

Mahsun. (1995). Dialektologi diakronis sebuah pengantar. Yogyakarta, Gadjah Mada Universitas Press.

Media Sandra Kasih. (2004). Kata sapaan bahasa Minangkabau cerminan adat dan sistem sosial. Serdang, Penerbit Universiti Putra Malaysia.

Moussay, Gerard. (1981). la language Minangkabau. Jakarta, Gramedia.

Nadra. (1997). Geografi dialek bahasa Minangkabau. Disertasi Doktor Falsafah. Universiti Gajah Mada, Jogjakarta.

Nadra. (2006). Rekonstruksi bahasa Minangkabau. Andalas University Press.

Rahim Aman. (2005). Rekonstruksi dan klasifikasi bahasa Bidayuhik Utara Purba (BUP). Tesis Ijazah Doktor Falsafah. Institut Alam dan Tamadun Melayu. Universiti Kebangsaan Malaysia.

Reniwati. (2012). Bahasa Minangkabau dan dialek Negeri Sembilan: Satu tinjauan perbandingan linguistik historis komparatif. Wacana Etnik, Jurnal Ilmu Sosial dan Humaniora, 3(1), 7186.

Shahidi A.H., Mohamad Firdaus Azaharuddin, Rahim Aman \& Muhamad Syahmi Shabri. (2020). Pemetaan isoglos varian dialek Terengganu berasaskan aplikasi sistem maklumat geografi. Geografia-Malaysian Journal of Society and Space, 16(4), 179-196.

Sudaryanto. (1988). Metode linguistik bagian kedua. metode dan aneka teknik pengumpulan data. Gadjah Mada University Press.

Tamsin Medan. (1986). Geografi dialek bahasa Minangkabau: Suatu deskripsi dan pemetaan di daerah Kabupaten Pasaman. Jakarta, Pusat Pembinaan dan Pengembangan Bahasa Departemen Pendidikan dan Kebudayaan Jakarta. 